\title{
Effects of Renin Gene Transfer on Blood Pressure and Renin Gene Expression in a Congenic Strain of Dahl Salt-resistant Rats
}

\author{
Elizabeth M. St. Lezin,, Michal Pravenec, ${ }^{\ddagger}$ Antonio L. Wong, ${ }^{\star}$ Weizhong Liu, ${ }^{\star}$ Ning Wang, ${ }^{\star}$ Shanhong Lu, ${ }^{*}$ Howard J. Jacob, ${ }^{\S}$ \\ Richard J. Roman, $\|$ David E. Stec, Jia-Ming Wang, ${ }^{*}$ lan A. Reid," and Theodore W. Kurtz* \\ *Department of Laboratory Medicine, University of California, San Francisco, San Francisco, California 94143; ${ }^{\ddagger}$ Institute of Physiology, \\ Czech Academy of Sciences, 14220 Prague 4, Czech Republic; ${ }^{\S}$ Cardiovascular Research Center, Massachusetts General Hospital, \\ Charleston, Massachusetts 02129; "Department of Physiology, Medical College of Wisconsin, Milwaukee, Wisconsin 53226; and \\ "Department of Physiology, University of California, San Francisco, San Francisco, California 94143
}

\begin{abstract}
To investigate whether a BP-regulatory locus exists in the vicinity of the renin locus on rat chromosome 13 , we transferred this chromosome segment from the Dahl salt-sensitive (S) rat onto the genetic background of the Dahl saltresistant $(R)$ rat. In congenic Dahl $R$ rats carrying the $S$ renin gene and fed an $8 \%$ salt diet, systolic $B P$ was significantly lower than in progenitor Dahl R rats: $127 \pm 1 \mathrm{mmHg}$ versus $138 \pm 4 \mathrm{mmHg}$, respectively $(P<0.05)$. Moreover, the decreased BP in the congenic Dahl $R$ strain was associated with decreased kidney renin mRNA and decreased plasma renin concentration. These findings demonstrate that the Dahl S strain carries alleles in or near the renin locus that confer lower plasma renin concentration and lower BP than the corresponding alleles in the Dahl R strain, at least when studied on the genetic background of the Dahl $R$ rat and in the environment of a high salt diet. The occurrence of coincident reductions in kidney renin $\mathrm{mRNA}$, plasma renin concentration, and BP after interstrain transfer of naturally occurring renin gene variants strongly suggests that genetically determined variation in renin gene expression can affect BP. (J. Clin. Invest. 1996. 97:522-527.) Key words: rat, inbred Dahl salt sensitive - genetics • hypertension • reninangiotensin system
\end{abstract}

\section{Introduction}

The renin-angiotensin system (RAS) $)^{1}$ plays an important physiologic role in the regulation of BP. The genes coding for the components of the RAS, including renin, angiotensinogen, angiotensin-converting enzyme, and the angiotensin receptors, are all prime candidate genes for essential hypertension (1). In studies in humans and animals, polymorphisms in or near

Address correspondence to Elizabeth St. Lezin, M.D., Department of Laboratory Medicine, UCSF/Mt. Zion Medical Center, POB 7921, San Francisco, CA 94120. Phone: 415-885-7440; Fax: 415-885-7522; E-mail: stlezin@labmed.ucsf.edu

Received for publication 18 August 1995 and accepted in revised form 19 October 1995.

1. Abbreviations used in this paper: DBP, diastolic BP; LH, Lyon hypertensive; QTL, quantitative trait locus; R, salt resistant; RAS, renin-angiotensin system; S, salt sensitive; SBP, systolic BP; SHR, spontaneously hypertensive rat.

J. Clin. Invest.

(C) The American Society for Clinical Investigation, Inc.

0021-9738/96/01/522/06 \$2.00

Volume 97, Number 2, January 1996, 522-527 genes of the RAS have been reported to be genetically linked or associated with effects on BP (2-10). Because of the central role of the renin-angiotensin axis in controlling salt and water balance, gene variants in the RAS may also be important in determining individual differences in the $\mathrm{BP}$ response to $\mathrm{NaCl}$ loading.

In linkage studies in the Dahl salt-sensitive (S) rat, a widely studied model of salt-sensitive hypertension, Rapp et al. (2) found that a restriction fragment-length polymorphism in the renin gene cosegregated with effects on BP. In an F2 population derived from Dahl S and Dahl salt-resistant (R) rats, the $\mathrm{BP}$ of rats that inherited the renin allele from the hypertensive $\mathrm{S}$ strain was greater than the $\mathrm{BP}$ of rats that inherited the renin allele from the normotensive $\mathrm{R}$ strain. These linkage studies suggested that molecular variation in or near the renin gene might contribute to the greater BP in Dahl S versus Dahl R rats. However, plasma renin levels are lower in Dahl $\mathrm{S}$ versus Dahl $R$ rats $(11,12)$, and it is unclear how inheritance of the $S$ renin allele would confer greater BP than inheritance of the $\mathrm{R}$ renin allele. Moreover, as noted by Rapp and colleagues, linkage studies in which a single genetic marker is found to cosegregate with a complex phenotype must be interpreted with caution $(13,14)$. It is possible that the positive linkage results might reflect the hemodynamic effect of a gene linked to renin on chromosome 13 rather than renin itself.

In contrast to studies in segregating populations, chromosome transfer studies in congenic strains can be used to isolate chromosome regions that contain quantitative trait loci regulating $\mathrm{BP}$ and to test directly their importance in the pathogenesis of hypertension (14-17). To investigate whether a segment of chromosome 13 containing the renin gene of the Dahl S rat would promote increased BP when transferred into the Dahl $\mathrm{R}$ rat, we derived a congenic strain of Dahl $\mathrm{R}$ rats that is homozygous for the Dahl S renin gene. We found that the BP of the congenic Dahl R strain carrying the $S$ renin gene is significantly lower than that of the progenitor Dahl R strain when studied in the environment of a high salt diet. Moreover, the lower BP in the congenic Dahl R strain carrying the $\mathrm{S}$ renin gene was associated with decreased expression of the renin gene in the kidney and decreased plasma concentration of renin. These findings demonstrate that the Dahl S strain carries alleles in or near the renin locus that confer lower levels of renin and BP than the corresponding alleles in the Dahl R strain, at least when studied on the genetic background of the Dahl R rat and in the environment of a high salt diet.

\section{Methods}

Breeding protocol. Inbred male Dahl S rats ( $\mathrm{SS} / \mathrm{Jr}$ strain, hereafter referred to as $\mathrm{S}$ ) and female Dahl R rats (SR/Jr strain, hereafter re- 
ferred to as R) were initially obtained from Harlan Sprague Dawley, Inc. (Indianapolis, IN) in 1990. No additional Dahl S rats were introduced into the R congenic strain after 1990. Therefore, the problem of genetic contamination of the Dahl S strain that occurred after 1990 (18) does not affect the results of the current studies in the Dahl R congenic strain. However, subsequent transfer of the Dahl R renin allele onto the Dahl S genetic background had to be aborted because of genetic contamination of Dahl S rats supplied by Harlan Sprague Dawley.

The Dahl S renin gene was transferred into the R strain by backcross breeding combined with selection at multiple genetic markers polymorphic between the $\mathrm{S}$ and $\mathrm{R}$ progenitor strains. In the backcross progeny, we repeatedly selected for inheritance of the $S$ renin gene and against inheritance of other $S$ genes not on chromosome 13. This negative selection protocol served to accelerate production of the congenic line $(17,19,20)$. The progenitor Dahl R sex chromosomes were fixed in the N3 generation. After six generations of backcross breeding and selection using genetic markers, we intercrossed the animals to fix the $\mathrm{S}$ renin gene in the homozygous state and then verified the congenic status of the strain (see DNA typing studies). The new congenic line was designated SR/JrUcsf-Ren according to the nomenclature recommended by the Committee on Rat Nomenclature of the Institute of Laboratory Animal Resources (21).

DNA typing studies. Genomic DNA was isolated from tail tissue or fixed, dried blood samples. Renin genotyping was performed by testing three separate sites in the rat renin gene known to be polymorphic in the $\mathrm{S}$ and $\mathrm{R}$ strains using the following procedures: $(a)$ Southern analysis of a BglII polymorphism generated by a 38-bp tandem repeat in the first intron $(2,3)$; (b) PCR amplification of a polymorphic HindIII site in the fifth intron $(18,22)$; and (c) PCR amplification of a CT microsatellite in the third intron (13).

For purposes of genomic selection, we used DNA fingerprint analysis and PCR analysis of microsatellite markers scattered throughout the genome. DNA fingerprint analysis was performed by Southern blot analysis using oligonucleotide multilocus DNA fingerprint probes including the 33.6 and YNZ22 human minisatellite tandem repeat sequences (23-25) and three microsatellite tandem repeat probes $\left([\mathrm{GACA}]_{4},[\mathrm{CT}]_{8}\right.$, and $\left.[\mathrm{CACA}]_{5}\right)(26,27)$. Genotyping by PCR analysis of microsatellite markers was done using primers amplifying 30 polymorphic markers on 18 different chromosomes (including chromosome 13). The PCR primers used for genotyping were primarily those described by Jacob et al. (28) and were obtained from Research Genetics (Huntsville, AL) (D1Mit2, D3Mit13, D4Mit9, D5Mit4, D5Mit11, D5Mit13, D5Mit14, D6Mit9, D7Mit13, D8Mit12, D10Mgh10, D12Mit6, D13Mit1, D13Mit3, D13Mit5, D14Mit1, D14Mit7, D17Mit3, D17Mit7, D18Mit1, D18Mit9, D19Mgh4, and D20Mit4). Additional markers were synthesized by the University of California, San Francisco Biomolecular Resource Center from previously published sequences of Serikawa et al. (Cpb, Csmop2, Prlr, $R 28$, and Spr) (29) and Remmers et al. (Syt2, D13n1) (30).

$B P$ studies. At weaning, congenic $\mathrm{R}$ rats (seven male, eight female) and age-matched progenitor $\mathrm{R}$ rats (eight male, eight female) were fed an $8 \% \mathrm{NaCl}\left(0.5 \% \mathrm{KHCO}_{3}\right)$ diet (Harlan Teklad, Madison, WI). Beginning at $8 \mathrm{wk}$ of age for males and $10 \mathrm{wk}$ of age for females, pulsatile arterial pressure was measured in unanesthetized, unrestrained rats with indwelling radiotelemetry transducers connected to catheters implanted in the lower abdominal aorta (Data Sciences International, Inc., St. Paul, MN) (31). Radiotelemetry pressure was recorded in 5-s bursts every 5 min during the day (6:00 a.m.-6:00 p.m.) and night (6:00 p.m.-6:00 a.m.) for 1 wk. From these data, a single daytime mean and a single nighttime mean were calculated for each rat for the week (after $55 \mathrm{~d}$ on the $8 \% \mathrm{NaCl}$ diet for males and after $69 \mathrm{~d}$ on the $8 \% \mathrm{NaCl}$ diet for females). The congenic and progenitor strains were studied concurrently to minimize the influence of technical or environmental factors on strain differences in BP.

In a separate study, we intercrossed congenic Dahl $\mathrm{R}$ rats that had been maintained in the heterozygous state with respect to the Dahl S and $\mathrm{R}$ renin alleles. This intercross generated congenic rats homozygous for the $\mathrm{S}$ renin allele and littermates homozygous for the $\mathrm{R}$ renin allele. Male rats in each group $(n=7)$ were fed a low salt diet $(0.24 \% \mathrm{NaCl})$ from weaning to $11 \mathrm{wk}$ of age, followed by a $2 \% \mathrm{NaCl}$ diet from 11 to 13 wk of age. BP was measured by radiotelemetry from 10 to 11 wk of age on the low salt diet and from 12 to 13 wk of age on the $2 \% \mathrm{NaCl}$ diet.

Kidney renin expression/plasma renin measurements. Nine male congenic $\mathrm{R}$ rats and 8 male progenitor $\mathrm{R}$ rats were fed a low salt $(0.24 \% \mathrm{NaCl})$ diet beginning at weaning. At 11 wk of age, the rats were salt depleted by subcutaneous injection of furosemide, $7 \mathrm{mg} / \mathrm{kg}$ per $\mathrm{d}$, for $2 \mathrm{~d}$. Blood samples were collected for plasma renin concentration via an indwelling femoral artery catheter from resting rats between noon and 3:00 p.m. The rats were then anesthetized by intramuscular injection of $75 \mathrm{mg} / \mathrm{kg}$ ketamine and $10 \mathrm{mg} / \mathrm{kg}$ xylazine, and the left kidney was removed and frozen for RNA analysis. The rats were allowed to recover and were then fed a $2 \% \mathrm{NaCl}$ diet for $12 \mathrm{~d}$, after which time a second blood sample was obtained. The rats were then killed, and the remaining kidneys were collected for RNA analysis.

Total kidney RNA was extracted using a large-scale isolation kit (5 Prime-3 Prime, Inc., Boulder, CO). Kidney renin mRNA expression was analyzed by RNase protection assay using a renin cRNA probe prepared by transcription of a renin cDNA fragment cloned in pCR II (Invitrogen, San Diego, CA). The renin RNA probe was a 412-base probe containing 304 bases of rat renin cDNA spanning exons 3,4 , and 5 of the rat renin gene. To serve as an internal standard, a rat actin RNA probe was also transcribed using a commercially available antisense actin template (pTRI- $\beta$-I25-rat; Ambion, Inc., Austin, TX) that protects a 125-base actin RNA fragment. Renin and actin probes were transcribed using T7 polymerase (MAXIscript; Ambion, Inc.) and $50 \mu \mathrm{Ci}\left[{ }^{32} \mathrm{P}\right] \mathrm{ATP}$ (Amersham, Inc., Arlington Heights, IL).

RNase protection assays were performed using the Ribonuclease Protection Assay II kit (Ambion, Inc.). Briefly, for each rat, $70 \mu \mathrm{g}$ of kidney total RNA was hybridized overnight at $42^{\circ} \mathrm{C}$ with both ${ }^{32} \mathrm{P}$-labeled renin probe $\left(8 \times 10^{5} \mathrm{cpm}\right)$ and ${ }^{32} \mathrm{P}$-labeled actin probe $\left(6 \times 10^{5} \mathrm{cpm}\right)$. Unhybridized probe and RNA fragments were removed by digestion with a 1:500 dilution of RNase A/RNase T1 mixture in RNase digestion buffer. After RNase inactivation and precipitation of the protected RNA fragments, samples were analyzed on a $5 \%$ denaturing polyacrylamide gel. Kidney renin mRNA expression was quantitated by scanning gels using a PhosphorImager (Molecular Dynamics, Inc., Sunnyvale, CA) and calculating the percentage of kidney renin message relative to kidney actin message.

Plasma renin concentration was measured by radioimmunoassay as previously described and expressed as nanograms of angiotensin I generated per milliliter of plasma during a 2-h incubation with excess substrate at $37^{\circ} \mathrm{C}$ and $\mathrm{pH} 6.5(\mathrm{ng} / \mathrm{ml}$ per $2 \mathrm{~h})(32)$. Statistical analysis of the BP and renin data was performed using the Mann Whitney rank sum test. For purposes of data presentation, the results are expressed as means $( \pm$ SEM) rather than median values.

\section{Results}

Molecular genetic analysis of the congenic strain. DNA fingerprint and PCR analysis of microsatellite markers scattered throughout the genome confirmed that the congenic line was genetically identical to the Dahl $\mathrm{R}$ progenitor strain at all loci tested except for those on chromosome 13. Fig. 1 shows Southern blot and PCR gels demonstrating that the congenic R strain is homozygous for the $\mathrm{S}$ renin allele at two polymorphic sites in introns one and five in the renin gene. PCR analysis of a polymorphic microsatellite marker in the third intron of the renin gene also confirmed that the congenic strain was homozygous for the $\mathrm{S}$ renin allele (data not shown). Thus, the congenic strain has the same renin haplotype as the Dahl S strain. Because the Dahl S and Lewis strains have similar renin 


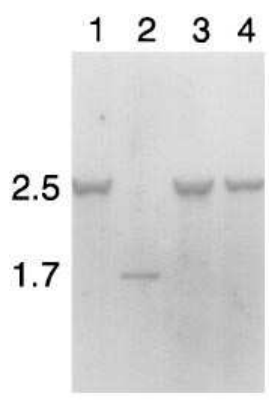

A

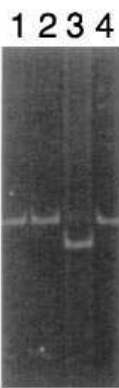

B
149 121
Figure 1. Renin genotyping results in representative congenic and progenitor Dahl rats. (A) Southern blot analysis of an RFLP in the renin gene of a Dahl $S$ rat (lane 1), a Dahl R rat (lane 2), and two congenic $\mathrm{R}$ rats homozygous for the $\mathrm{S}$ renin gene (lanes 3 and 4). BglII-digested genomic DNA was hybridized

with a probe complementary to the 38 -bp tandem repeat sequence in the first intron of the renin gene. The left margin indicates band size in kilobases. (B) PCR analysis of a HindIII RFLP in the fifth intron of the renin gene of congenic $\mathrm{R}$ rats homozygous for the $\mathrm{S}$ renin gene (lanes 1 and 2), a progenitor Dahl $\mathrm{R}$ rat (lane 3), and a Dahl S rat (lane 4). Right margin indicates PCR fragment size in base pairs.

haplotypes (13), we tested markers flanking renin to confirm that the transferred chromosome segment was from a Dahl S rat and not from a Dahl $\mathrm{S}$ rat contaminated by the Lewis strain. PCR analysis of three additional chromosome 13 markers polymorphic between the Dahl $\mathrm{S}$ and Lewis strains (D13Mgh4, D13Mit2, and D13Mgh7) (28) showed that, for each marker tested, the congenic strain was homozygous for the Dahl S allele.

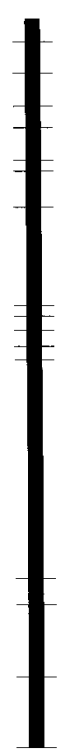

Dahl S
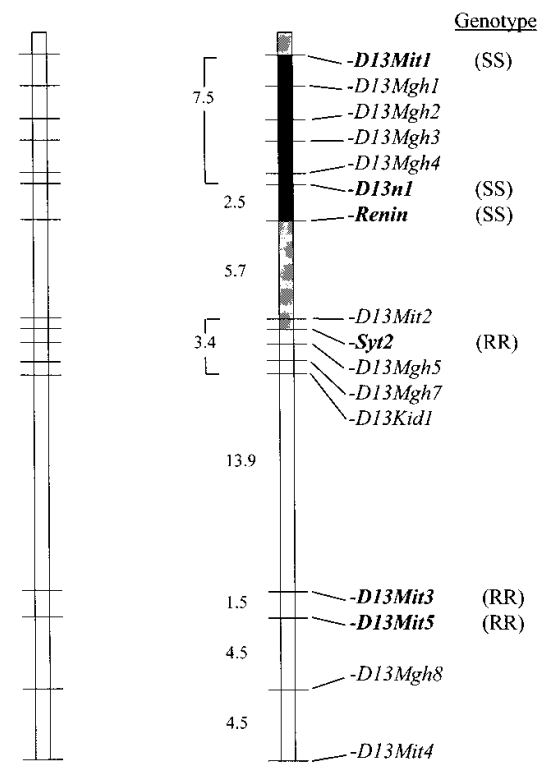

Figure 2. Linkage map of rat chromosome 13 in the congenic R strain showing the estimated size of the transferred chromosome segment. Markers shown in bold type are polymorphic between Dahl S and Dahl R rats and were genotyped in the congenic and progenitor strains. Markers shown in regular type are not polymorphic between the Dahl S and R strains and therefore were not informative for genotyping the congenic and progenitor rats. The Dahl S chromosome segment is denoted by the solid bar, and the progenitor R segment is denoted by the open bar. The upper and lower boundaries of the transferred chromosome segment lie within the shaded regions. Map distances are a composite drawn from the chromosome 13 maps of Jacob et al. (28) and Remmers et al. (30).
Table I. BPs of Congenic $R$ versus Progenitor $R$ Rats $\mathrm{Fed} 8 \% \mathrm{NaCl}$

\begin{tabular}{|c|c|c|c|c|}
\hline \multirow[b]{2}{*}{$\begin{array}{l}\text { Strain: } \\
\text { Renin } \\
\text { genotype: }\end{array}$} & \multicolumn{2}{|c|}{ Males } & \multicolumn{2}{|c|}{ Females } \\
\hline & $\begin{array}{c}\text { Congenic R } \\
\mathrm{S}\end{array}$ & $\begin{array}{c}\text { Progenitor R } \\
\text { R }\end{array}$ & Congenic R & $\begin{array}{c}\text { Progenitor R } \\
\text { R }\end{array}$ \\
\hline & $n=8$ & $n=7$ & $n=8$ & $n=8$ \\
\hline \multicolumn{5}{|l|}{ SBP } \\
\hline Night & $136 \pm 1 *$ & $144 \pm 4$ & $122 \pm 2^{\ddagger}$ & $128 \pm 2$ \\
\hline Day & $127 \pm 1^{\S}$ & $138 \pm 4$ & $118 \pm 2^{\|}$ & $124 \pm 2$ \\
\hline \multicolumn{5}{|l|}{ DBP } \\
\hline Night & $102 \pm 1$ & $105 \pm 4$ & $89 \pm 1$ & $89 \pm 1$ \\
\hline Day & $89 \pm 1$ & $95 \pm 4$ & $82 \pm 1$ & $83 \pm 1$ \\
\hline
\end{tabular}

BP in congenic Dahl R rats carrying the Dahl S renin gene and in progenitor Dahl R rats. Male rats were fed an $8 \% \mathrm{NaCl}$ diet for $\sim 8 \mathrm{wk}$; female rats were fed an $8 \% \mathrm{NaCl}$ diet for $\sim 10 \mathrm{wk}$. Each value represents the mean $( \pm$ SEM) of all daytime $(6: 00$ a.m-6:00 p.m) or nighttime $(6: 00$ p.m.-6:00 a.m.) BP measurements obtained in each rat during the final week of $\mathrm{NaCl}$ feeding. Significant difference between congenic and progenitor strains by Mann Whitney rank sum test: ${ }^{*} P=0.04,{ }^{*} P=0.05$, ${ }^{\S} P=0.01, \| P=0.07$.

To determine the size of the chromosome segment transferred from the Dahl S strain into the Dahl R genetic background, we genotyped the congenic strain for five polymorphic microsatellite markers flanking the renin gene on chromosome 13: D13Mit1, D13Mit3, D13Mit5, D13n1, and Syt2. We found that the size of the chromosome fragment transferred was $\sim 10 \mathrm{cM}$, estimated from the map distances of Jacob et al. (28) and Remmers et al. (30) (see Fig. 2).

$B P$ measurements. BP was measured in Dahl $\mathrm{R}$ progenitor and congenic rats fed an $8 \% \mathrm{NaCl}$ diet for $8-10 \mathrm{wk}$. Table I shows the average daytime and nighttime BPs in male and female rats of both strains. In both males and females, systolic BP (SBP) was significantly lower in the congenic strain than in the progenitor R strain. In males, diastolic BPs (DBP) tended

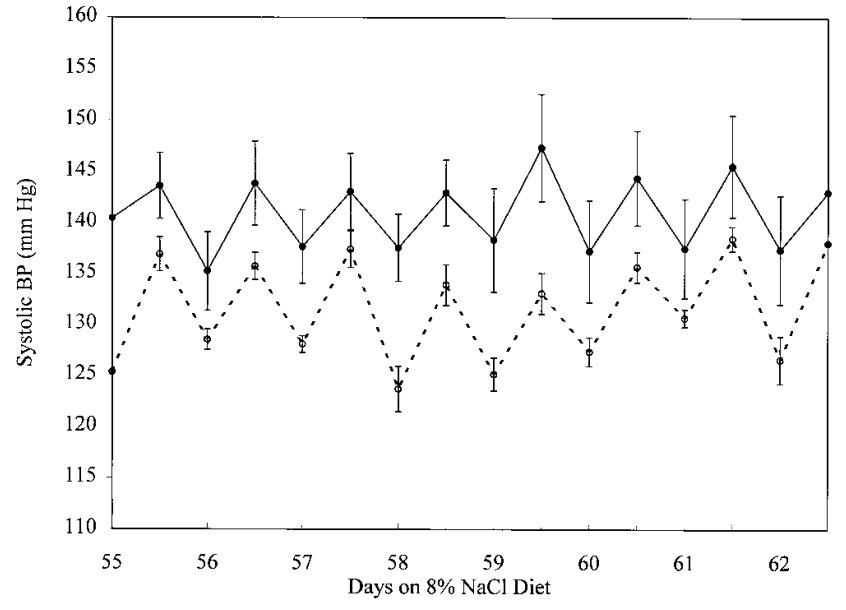

Figure 3. Daytime and nighttime SBPs of male congenic Dahl $\mathrm{R}$ rats (--O- ) and progenitor Dahl $\mathrm{R}$ rats (- - ) after $55 \mathrm{~d}$ on an $8 \%$ $\mathrm{NaCl}$ diet. Each data point represents the mean $( \pm$ SEM) of $\sim 1000$ daytime or nighttime BP measurements obtained in each of the eight congenic and seven progenitor $\mathrm{R}$ rats. The sawtooth pattern reflects the circadian variation in $\mathrm{BP}$. 


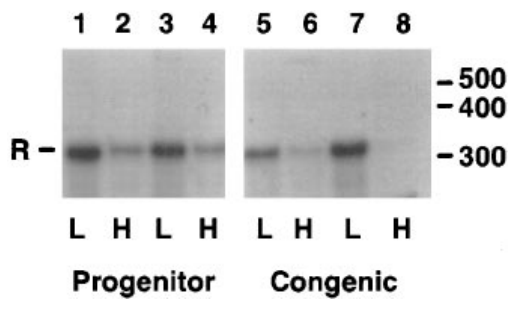

Figure 4. RNase protection analysis of kidney renin gene expression in representative progenitor and congenic Dahl $\mathrm{R}$ rats. Lanes $1-4$ show kidney renin gene expression in two progenitor $\mathrm{R}$ rats.

Kidney mRNA from each rat was analyzed first on a low $(0.24 \%)$ $\mathrm{NaCl} \operatorname{diet}(L)$ and then on a high $(2 \%) \mathrm{NaCl} \operatorname{diet}(H)$. Lanes $5-8$ show kidney renin gene expression in two congenic $\mathrm{R}$ rats carrying the $\mathrm{S}$ renin allele under similar conditions of low $\mathrm{NaCl}(L)$ and then high $\mathrm{NaCl}(H)$ feeding. Right margin indicates fragment size in base pairs. $R$, renin mRNA protected fragment.

to be lower in the congenic strain than in the progenitor strain, but the difference was not statistically significant. There were no significant differences in heart weight between the congenic $\mathrm{R}$ and the progenitor $\mathrm{R}$ rats (data not shown). Fig. 3 depicts the nighttime and daytime SBPs of congenic male $\mathrm{R}$ rats versus progenitor $\mathrm{R}$ rats during each day of the 7-d analysis period. The SBP of the congenic strain was significantly lower than that of the progenitor strain throughout the entire period of observation.

$\mathrm{BP}$ was also measured in male rats fed low $(0.24 \%) \mathrm{NaCl}$ and moderate $(2 \%) \mathrm{NaCl}$ diets. On the $2 \% \mathrm{NaCl}$ diet, both $\mathrm{SBP}$ and DBP in the congenic $\mathrm{R}$ rats carrying the $\mathrm{S}$ renin gene were significantly lower than in their $\mathrm{R}$ littermates carrying the $\mathrm{R}$ renin gene. The daytime mean $\mathrm{SBP} \pm \mathrm{SEM}$ was $118 \pm 2.4$ $\mathrm{mmHg}$ in the congenic rats versus $126 \pm 2.2 \mathrm{mmHg}$ in the progenitor $\mathrm{R}$ rats; nighttime mean $\mathrm{SBP} \pm \mathrm{SEM}$ was $121 \pm 2.2$ $\mathrm{mmHg}$ in the congenic rats versus $131 \pm 2.9 \mathrm{mmHg}$ in the progenitors, both differences $P=0.01$. The daytime mean DBP \pm SEM was $85 \pm 2.4 \mathrm{mmHg}$ in the congenic rats versus $91 \pm 2.6$ $\mathrm{mmHg}$ in the progenitor $\mathrm{R}$ rats; nighttime mean $\mathrm{DBP} \pm \mathrm{SEM}$ was $86 \pm 2.3 \mathrm{mmHg}$ in the congenic rats versus $93 \pm 2.7 \mathrm{mmHg}$ in the progenitor rats, $P=0.05$ and 0.04 , respectively. On the $0.24 \% \mathrm{NaCl}$ diet, the SBP and DBP were not significantly different between the congenic and progenitor strains, although

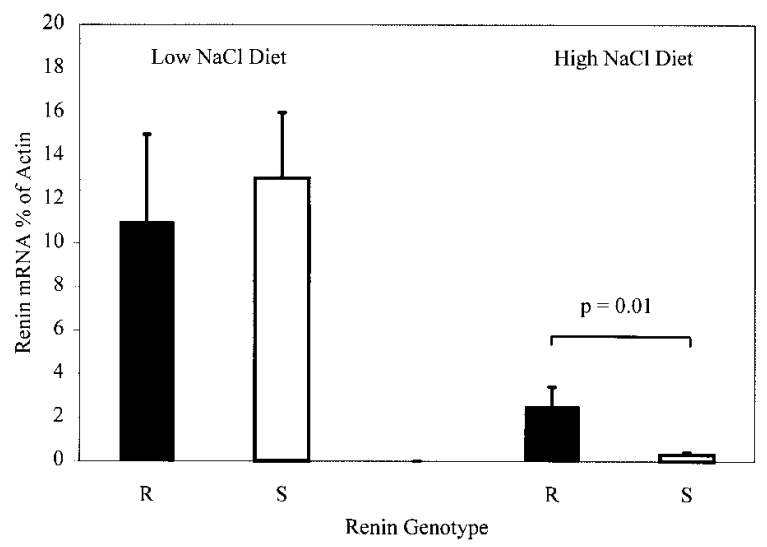

Figure 5. Quantitative kidney renin gene expression in $\mathrm{R}$ rats and congenic $\mathrm{R}$ rats fed low $(0.24 \%)$ and high $(2 \%) \mathrm{NaCl}$ diets. Solid bars represent progenitor Dahl $\mathrm{R}$ rats carrying the $\mathrm{R}$ renin gene $(n=6)$; open bars represent congenic Dahl $\mathrm{R}$ rats carrying the $\mathrm{S}$ renin gene $(n=7)$. Mean $( \pm$ SEM $)$ renin mRNA is expressed as a percentage of actin mRNA. The $P$ value represents the significance result from a comparison of the two groups by the Mann Whitney rank sum test. both SBP and DBP tended to be lower in the congenic strain than in the progenitor strain (daytime mean SBP/DBP was $117 / 83 \pm 2.9 / 2.8 \mathrm{mmHg}$ in the congenic strain versus 123/ $86 \pm 1.7 / 1.7 \mathrm{mmHg}$ in the progenitor strain; nighttime mean SBP/DBP was $120 / 86 \pm 2.8 / 2.6$ in the congenic strain versus $126 / 90 \pm 1.7 / 1.8 \mathrm{mmHg}$ in the progenitor strain).

Renin gene expression and plasma renin concentrations. To investigate possible differences in renin gene regulation between the congenic and progenitor strains, we measured kidney renin mRNA expression on both low and high salt diets. Fig. 4 shows kidney renin gene expression in congenic rats versus progenitor rats on low $(0.24 \%)$ and high $(2 \% \mathrm{NaCl})$ diets. On the low salt diet, kidney renin gene expression was similar in the congenic and progenitor rats. However, in congenic rats fed the $2 \%$ salt diet, kidney renin gene expression was significantly lower than in progenitor rats fed the $2 \%$ salt diet $(P=$ 0.01) (Fig. 5).

To determine whether differences in kidney renin gene expression were paralleled by differences in plasma renin levels, we also measured daytime plasma renin concentration in the congenic and progenitor rats fed low and moderate salt diets. On the $2 \% \mathrm{NaCl}$ diet, plasma renin concentration was significantly lower in the congenic versus the progenitor rats $(P=$ 0.04) (Fig. 6). However, on the low salt diet, plasma renin concentration was not significantly different in the two strains.

\section{Discussion}

In humans and experimental animals, it is well recognized that pharmacologic manipulation of the RAS can affect BP. Studies in transgenic and gene-targeted animals have clearly demonstrated that artificially induced genetic lesions in the RAS can affect BP $(33,34)$. Moreover, linkage and association studies suggest that naturally occurring molecular variants in genes of the RAS may be involved in the genetic control of BP (2-10). If so, transfer of naturally occurring RAS gene variants between animals might be anticipated to affect BP.

We found that transfer of a section of chromosome 13 from the Dahl S rat onto the genetic background of the Dahl R rat results in decreases in kidney renin gene expression, plasma

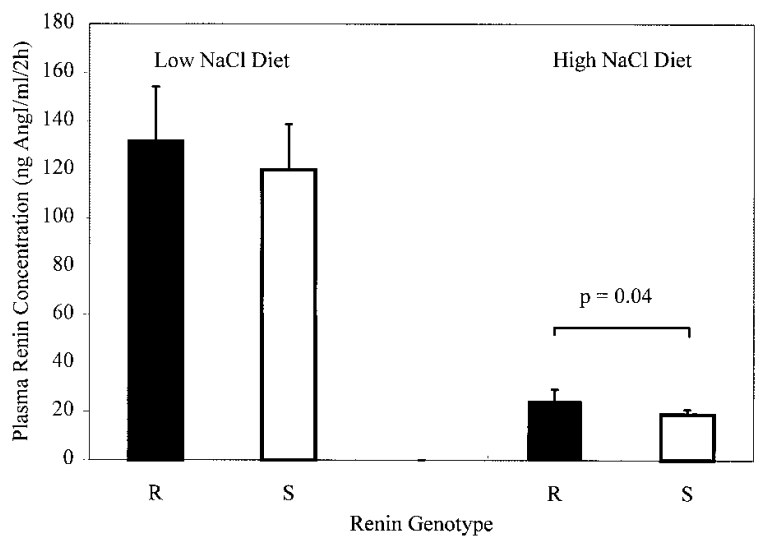

Figure 6. Plasma renin concentration in $\mathrm{R}$ rats and congenic $\mathrm{R}$ rats fed low $(0.24 \%)$ and high $(2 \%) \mathrm{NaCl}$ diets. Solid bars represent the mean $( \pm$ SEM) of eight progenitor $\mathrm{R}$ rats; open bars represent the mean of nine congenic R rats carrying the $\mathrm{S}$ renin gene. The $P$ value represents the significance result from a comparison of the two groups by the Mann Whitney rank sum test. 
renin concentration, and $\mathrm{BP}$ that can be detected in the environmental circumstance of a high $\mathrm{NaCl}$ diet. These findings demonstrate that the Dahl S strain carries a gene or genes on chromosome 13 that confer lower plasma renin and lower BP than the corresponding gene(s) in the Dahl R strain, at least when studied on the Dahl $\mathrm{R}$ genetic background and in the setting of a high $\mathrm{NaCl}$ diet. Transfer of this chromosome segment appeared to have a slightly greater effect on systolic pressure than diastolic pressure, suggesting that this region of chromosome 13 may contain genes with greater effects on arterial compliance or systolic function than on vascular resistance.

Because we manipulated a segment of chromosome 13 that contained the renin gene and genes linked to renin, the reductions in renin gene expression, plasma renin concentration, and BP cannot be definitively attributed to molecular variants in the renin gene itself. However, the results clearly demonstrate that the transferred segment of chromosome contains molecular variants with detectable effects on renin gene expression and BP. Thus, regardless of whether or not molecular variants in the renin gene itself or in genes linked to renin account for these findings, the current results are consistent with the hypothesis that genetically determined variation in the activity of the RAS may contribute to inherited variation in BP. Although it is possible that the transferred segment of chromosome 13 contains separate molecular variants that independently affect renin gene expression and BP, the simplest interpretation would involve molecular variant(s) that affect BP by way of effects on renin gene function. These alternative interpretations can now be further explored by pharmacologic studies in the congenic strains and by derivation of congenic sublines that carry smaller segments of chromosome 13 that isolate renin from other genes in this region.

In the congenic $\mathrm{R}$ strain carrying the $\mathrm{S}$ renin gene, $\mathrm{BP}$ and plasma renin concentration were lower than in the progenitor Dahl $\mathrm{R}$ strain. Thus, the reductions in plasma renin associated with the $S$ renin gene cannot be secondary to an effect of BP. If anything, the reduced BP in the congenic strain would be expected to increase renin gene expression and renin secretion. In the Dahl S strain, plasma renin activity is lower than in the Dahl $\mathrm{R}$ rat, and it has been suggested that the decreased plasma renin activity in Dahl S rats is a consequence of their increased BP (12). However, renin secretion from isolated perfused Dahl S kidneys is lower than that from isolated perfused Dahl R kidneys, even when the S and R kidneys are studied at identical perfusion pressures (35). Thus, the current results and those obtained with isolated perfused kidneys imply that, in Dahl S rats, decreased renin levels may be related to genetically determined decreases in renin gene expression and are not just a consequence of hypertension. Sequencing studies have failed to reveal any significant differences in the renin cDNAs from Dahl S and Dahl R rats, and, therefore, the differences in renin gene function cannot be attributed to variations in coding sequence (36). However, in the noncoding regions, these strains exhibit a number of sequence differences that could theoretically contribute to differences in renin gene expression (22).

In linkage studies in the Dahl model, Rapp et al. found that the renin allele of the $S$ strain cosegregated with increased BP relative to the renin allele of the $\mathrm{R}$ strain (2). In contrast, we have found that the transfer of the Dahl S renin allele into the Dahl $\mathrm{R}$ rat is associated with a decrease in BP. Nevertheless, the previous linkage results are not necessarily at odds with our chromosome transfer studies in congenic strains. In previous linkage studies, the Dahl S renin allele was found to cosegregate with greater $\mathrm{BP}$ than the $\mathrm{R}$ renin allele when studied on the genetic background of the Dahl S rat, but not when studied on the genetic background of the Dahl $\mathrm{R}$ rat (37). Thus, it is conceivable that a hypertensive effect of the $\mathrm{S}$ renin allele might be expressed only in conjunction with other $\mathrm{S}$ alleles that are not present in the $\mathrm{R}$ congenic strain. For example, the $S$ renin allele might confer increased $B P$ over the $\mathrm{R}$ renin allele only when studied in combination with the $\mathrm{S}$ angiotensinogen allele. This could be investigated by comparing the $\mathrm{BP}$ of a Dahl S rat to the BP of a congenic Dahl S rat that carries the renin allele of the Dahl $\mathrm{R}$ rat. Alternatively, one could compare the BP of a Dahl R rat with that of a double congenic strain that carries both the $S$ renin allele and the $S$ angiotensinogen allele on the genetic background of the Dahl $\mathrm{R}$ rat.

In addition to possible interaction between the renin gene and genetic background, other explanations for the difference between the present findings and those of Rapp and colleagues should be considered. As emphasized by Rapp and others, linkage studies in which a single genetic marker is found to cosegregate with a complex phenotype must be interpreted with caution $(13,14)$. Linkage between a marker and $\mathrm{BP}$ indicates only that the marker lies in a broad chromosome region that contains a BP-regulatory locus. Thus, the results of the original linkage studies in Dahl $\mathrm{S}$ and $\mathrm{R}$ rats may reflect the presence of a BP quantitative trait locus (QTL) located at some distance from the renin locus on chromosome 13 . It is possible that, in the back-cross breeding process used to create the congenic lines, a BP QTL linked to the $\mathrm{S}$ renin gene on chromosome 13 was lost through recombination and not transmitted to the $\mathrm{R}$ congenic strain. Accordingly, the BP of the $\mathrm{R}$ congenic strain may reflect only the isolated effect of the Dahl $S$ renin gene, and not the effect of a linked gene that promotes increased BP. If so, studies in congenic strains that carry different overlapping segments of chromosome 13 should be useful for mapping the BP QTL detected in linkage studies in Dahl S and $\mathrm{R}$ rats. Finally, it is possible that differences in the duration of $\mathrm{NaCl}$ feeding or in other environmental factors (e.g., stress associated with the BP measurements) might contribute to the different $\mathrm{BP}$ results in the congenic strains versus those in the segregating populations studied by Rapp and colleagues.

It might seem paradoxical to suggest that the hypertensive Dahl S strain carries a renin allele that promotes lower BP than the renin allele fixed in the normotensive Dahl $\mathrm{R}$ strain. However, the fact that the BP of the Dahl S strain is much greater than that of the Dahl R strain does not imply that every BP gene in the $\mathrm{S}$ strain promotes greater pressure than every $\mathrm{BP}$ gene in the $\mathrm{R}$ strain. Hypertension in the $\mathrm{S}$ rat stems from the net effect of multiple genes on BP, some of which may promote increased BP and some of which may promote decreased BP. Thus, it should not be surprising if the Dahl S strain has fixed a renin allele that promotes lower BP than the renin allele fixed in the Dahl $\mathrm{R}$ strain.

In genetic studies in the spontaneously hypertensive rat (SHR) and the Lyon hypertensive (LH) rat, renin gene polymorphisms have also been linked to effects on $\mathrm{BP}(3,38,39)$. Specifically, the renin alleles of the SHR and of the LH strain have been found to cosegregate with greater BP than those of the Brown Norway, Lewis, and Lyon normotensive strains. Based on haplotype analysis, it appears that both the SHR and LH rat carry the same molecular variant of renin that is found 
in the Dahl $\mathrm{R}$ rat (13). Thus, even though renin gene polymorphism may not contribute to hypertension in the Dahl model, it is possible that molecular variants of the renin gene contribute to increased BP in other models of hypertension. The fact that pharmacologic blockade of the RAS is much more effective in lowering BP in SHR than in Dahl S rats is consistent with this hypothesis (40).

In summary, we have found that transfer of the renin gene and a portion of chromosome 13 from the Dahl S rat into the Dahl $\mathrm{R}$ rat induces decreases in kidney renin gene expression, plasma renin concentration, and BP. These findings demonstrate that, in the Dahl S rat, molecular variants in or near the renin gene are not sufficient to promote hypertension in the Dahl R strain. However, the occurrence of coincident reductions in kidney renin mRNA, plasma renin concentration, and BP after interstrain transfer of naturally occurring renin gene variants strongly suggests that genetically determined variation in renin gene expression can contribute to naturally occurring genetic variation in $\mathrm{BP}$.

\section{Acknowledgments}

We are grateful to Dr. John Rapp and Dr. Alan Deng for their helpful discussion and critique of this manuscript.

This work was supported by grants from the National Institutes of Health (Hypertension Program Project PO1 HL-35018) (Bethesda, MD); the American Heart Association National Center (Dallas, TX); the American Heart Association, California Affiliate, Inc. (Burlingame, CA); and the Max and Victoria Dreyfus Foundation (New York)

\section{References}

1. Soubrier, F., and F. Cambien. 1993. Renin-angiotensin system genes as candidate genes in cardiovascular diseases. Trends Cardiovasc. Med. 3:250-258.

2. Rapp, J. P., S.-M. Wang, and H. Dene. 1989. A genetic polymorphism in the renin gene of Dahl rats cosegregates with blood pressure. Science (Wash. DC). 243:542-544.

3. Kurtz, T. W., L. Simonet, P. M. Kabra, S. Wolfe, L. Chan, and B. L. Hjelle. 1990. Cosegregation of the renin allele of the spontaneously hypertensive rat with an increase in blood pressure. J. Clin. Invest. 85:1328-1332.

4. Barley, J., N. D. Carter, J. K. Cruickshank, S. Jeffrey, A. Smith, A. Charlett, and D. J. Webb. 1991. Renin and atrial natriuretic peptide restriction fragment length polymorphisms: association with ethnicity and blood pressure. $J$. Hypertens. 9:993-996.

5. Jeunemaitre, X., F. Soubrier, Y. V. Kotelevtsev, R. P. Lifton, C. S. Williams, A. Charru, S. C. Hunt, P. N. Hopkins, R. R. Williams, J. M. Lalouel, and P. Corvol. 1992. Molecular basis of human hypertension: role of angiotensinogen. Cell. 71:169-180.

6. Jacob, H. J., K. Lindpaintner, S. E. Lincoln, K. Kusumi, R. K. Bunker, Y. P. Mao, D. Ganten, V. J. Dzau, and E. S. Lander. 1991. Genetic mapping of a gene causing hypertension in the stroke-prone spontaneously hypertensive rat. Cell. 67:213-224.

7. Hilbert, P., K. Lindpaintner, J. S. Beckmann, T. Serikawa, F. Soubrier, C. Dubay, P. Cartwright, B. DeGouyon, C. Julier, S. Takahasi, et al. 1991. Chromosomal mapping of two genetic loci associated with blood pressure regulation in hereditary hypertensive rats. Nature (Lond.). 353:521-529.

8. Deng, Y., and J. P. Rapp. 1992. Cosegregation of blood pressure with angiotensin converting enzyme and atrial natriuretic peptide receptor genes using Dahl salt-sensitive rats. Nat. Genet. 1:267-272.

9. Duru, K., S. Farrow, J. M. Wang, W. Lockette, and T. Kurtz. 1994. Frequency of a deletion polymorphism in the gene for angiotensin converting enzyme is increased in African-Americans with hypertension. Am. J. Hypertens. 7: 759-762.

10. Bonnardeaux, A., E. Davies, X. Jeunemaitre, I. Féry, A. Charru, E. Clauser, L. Tiret, F. Cambien, P. Corvol, and F. Soubrier. 1994. Angiotensin II type 1 receptor gene polymorphisms in human essential hypertension. Hypertension (Dallas). 24:63-69.

11. Iwai, J., L. K. Dahl, and K. D. Knudsen. 1973. Genetic influence on the renin-angiotensin system: low renin activities in hypertension-prone rats. Circ. Res. 32:678-684.

12. Rapp, J. P., S. Y. Tan, and H. S. Margolius. 1978. Plasma mineralocorticoids, plasma renin, and urinary kallikrein in salt-sensitive and salt-resistant rats. Endocr. Res. Commun. 5:35-41.
13. Rapp, J. P., H. Dene, and A. Y. Deng. 1994. Seven renin alleles in rats and their effects on blood pressure. J. Hypertens. 12:349-356.

14. Rapp, J. P., and A. Y. Deng. 1995. Detection and positional cloning of blood pressure quantitative trait loci: is it possible? Hypertension (Dallas). 25: 1121-1128.

15. Rapp, J. P. 1991. Dissecting the primary causes of genetic hypertension in rats. Hypertension (Dallas). 18:I18-I28.

16. St. Lezin, E. M., M. Pravenec, and T. W. Kurtz. 1993. New genetic models for hypertension research. Trends Cardiovasc. Med. 3:119-123.

17. Lander, E. S., and N. J. Schork. 1994. Genetic dissection of complex traits. Science (Wash. DC). 256:2037-2048.

18. St. Lezin, E. M., M. Pravenec, A. Wong, J. M. Wang, T. Merriouns, S. Newton, D. E. Stec, R. J. Roman, D. Lau, R. C. Morris, and T. W. Kurtz. 1994. Genetic contamination of Dahl SS/Jr rats: impact on studies of salt-sensitive hypertension. Hypertension (Dallas). 23:786-790.

19. Hillel, J., T. Schaap, A. Haberfeld, A. J. Jeffreys, Y. Plotzky, A. Cahaner, and U. Lavi. 1990. DNA fingerprints applied to gene introgression in breeding programs. Genetics. 124:783-789.

20. Hospital, F., C. Chevalet, and P. Mulsant. 1992. Using markers in gene introgression breeding programs. Genetics. 132:1199-1210.

21. Committee on Rat Nomenclature, Institute of Laboratory Animal Resources. 1992. Definition, nomenclature, and conservation of rat strains. ILAR News (National Academy Press, Wash., DC). 34:S1-S26.

22. Wang, S. M., and J. P. Rapp. 1989. Structural differences in the renin gene of Dahl salt-sensitive and salt-resistant rats. Mol. Endocrinol. 3:288-294.

23. Jeffreys, A. J., V. Wilson, and S. L. Thein. 1985. Hypervariable "minisatellite" regions in human DNA. Nature (Lond.). 314:67-73.

24. St. Lezin, E. M., L. Simonet, M. Pravenec, and T. W. Kurtz. 1992. Hypertensive strains and normotensive control strains: how closely are they related? Hypertension (Dallas). 19:419-424.

25. Nakamura, Y., M. Leppert, P. O'Connell, R. Wolff, T. Holm, M. Culver, C. Martin, E. Fujimoto, M. Hoff, E. Kumlin, and R. White. 1987. Variable number of tandem repeat (VNTR) markers for human gene mapping. Science (Wash. DC). 235:1616-1622.

26. Nurnberg, P., L. Roewer, H. Neitzel, K. Sperling, A. Popperl, J. Hundrieser, H. Poche, and J. Epplen. 1989. DNA fingerprinting with the oligonucleotide probe (CAC)5/(GTG)5: somatic stability and germline mutations. Hum. Genet. 84:75-78.

27. Ali, S., C. R. Muller, and J. T. Epplen. 1986. DNA fingerprinting by oligonucleotide probes specific for simple repeats. Hum. Genet. 74:239-243.

28. Jacob, H., D. Brown, R. Bunker, M. Daly, V. Dzau, A. Goodman, G. Koike, V. Kren, T. Kurtz, A. Lernmark, et al. 1995. A genetic linkage map of the laboratory rat. Nat. Genet. 9:63-69.

29. Serikawa, T., T. Kuramoto, P. Hilbert, M. Mori, J. Yamada, C. J. Dubay, K. Lindpainter, D. Ganten, J. L. Guenet, G. M. Lathrop, and J. S. Beckmann. 1992. Rat gene mapping using PCR-analyzed microsatellites. Genetics. 131:701-721.

30. Remmers, E. F., E. A. Goldmuntz, H. Zha, P. Mathern, Y. Du, L. J. Crofford, and R. L. Wilder. 1993. Linkage map of nine loci defined by polymorphic DNA markers assigned to rat chromosome 13. Genomics. 18:277-282.

31. Bazil, M. K., C. Krulan, and R. L. Webb. 1993. Telemetric monitoring of cardiovascular parameters in conscious spontaneously hypertensive rats. J. Cardiovasc. Pharmacol. 22:897-905.

32. Menard, J., and K. J. Catt. 1972. Measurement of renin activity, concentration and substrate in rat plasma by radioimmunoassay of angiotensin I. Endocrinology. 90:422-430.

33. Mullins, J. J., J. Peters, and D. Ganten. 1990. Fulminant hypertension in transgenic rats harbouring the mouse Ren-2 gene. Nature (Lond.). 344:541-544.

34. Kim, H. S., J. H. Krege, K. D. Kluckman, J. R. Hagaman, J. B. Hodgin, C. F. Best, J. C. Jennette, T. M. Coffman, N. Maeda, and O. Smithies. 1995. Genetic control of blood pressure and the angiotensinogen locus. Proc. Natl. Acad. Sci. USA. 92:2735-2739.

35. Tobian, L., J. Lange, S. Azar, J. Iwai, D. Koop, K. Coffee, and M. A. Johnson. 1978. Reduction of natriuretic capacity an renin release in isolated, blood-perfused kidneys of Dahl hypertension-prone rats. Circ. Res. 43(Supp 1): I92-I98.

36. Alam, K. Y., Y. Wang, H. Dene, and J. P. Rapp. 1993. Renin gene nucleotide sequence of coding and regulatory regions in Dahl rats. Clin. Exp. Hypertens. 15:599-614.

37. Rapp, J. P., S. M. Wang, and H. Dene. 1990. Effect of genetic background on cosegregation of renin alleles and blood pressure in Dahl rats. Am. J. Hypertens. 3:391-396.

38. Pravenec, M., L. Simonet, V. Kren, J. Kunes, G. Levan, J. Szpirer, C. Szpirer, and T. Kurtz. 1991. The rat renin gene: assignment to chromosome 13 and linkage to the regulation of blood pressure. Genomics. 9:466-472.

39. Dubay, C., M. Vincent, N. J. Samani, P. Hilbert, M. A. Kaiser, J.-P. Beressi, Y. Kotelevtsev, J. S. Beckmann, F. Soubrier, J. Sassard, and G. M. Lathrop. 1993. Genetic determinants of diastolic and pulse pressure map to different loci in Lyon hypertensive rats. Nat. Genet. 3:354-357.

40. Gahnem, F., N. von Lutterotti, M. J. Camargo, J. H. Laragh, and J. E. Sealey. 1994. Angiotensinogen dependency of blood pressure in two high-renin hypertensive rat models. Am. J. Hypertens. 7:899-904. 